\title{
Perlakuan Rizobakteri Pemacu Pertumbuhan Tanaman (RPPT) dengan Beberapa Tingkat Kerapatan Inokulum Rizobakteri Terhadap Viabilitas dan Vigor Benih Cabai Merah Kadaluarsa (Capsicum annuum L.)
}

\author{
(Treatment Of Plant Growth Promoting Rhizobacteria (PGPR)With Multiple Levels \\ of Rhizobacteria Inoculum Density On Viability and Vigor Of Expired Red Chilli \\ Seeds (Capsicum annuum L.)
}

\author{
Dayang Rahmanita Simanjuntak ${ }^{1}$, Halimursyadah ${ }^{1}$, Syamsuddin $^{1^{*}}$ \\ ${ }^{1}$ Program Studi Agroteknologi, Fakultas pertanian, Universitas Syiah Kuala \\ Corresponding author: syamsuddin@unsyiah.ac.id
}

\begin{abstract}
Abstrak. Biological seed treatment merupakan salah satu perlakuan benih menggunakan mikroorganisme seperti rizobakteri pemacu pertumbuhan tanaman (RPPT). Penelitian ini bertujuan untuk mengetahui jenis rizobakteri dan kerapatan inokulum yang dapat meningkatkan viabilitas dan vigor benih cabai kadaluarsa. Penelitian ini menggunakan Rancangan Acak Lengkap (RAL) pola faktorial dengan 2 faktor dan 3 ulangan. Faktor pertama adalah jenis rizobakteri $(\mathrm{R})$ terdiri atas lima taraf yaitu $\mathrm{R}_{1}$ : Necercia sp; $\mathrm{R}_{2}$ : Bacillus polymixa; $\mathrm{R}_{3}$ : Actinobacillus suis; $\mathrm{R}_{4}$ : Azotobacter $\mathrm{sp} ; \mathrm{R}_{5}$ : Pseudomonas capacia. Faktor kedua adalah kerapatan inokulum rizobakteri terdiri dari tiga taraf yaitu $\mathrm{K}_{1}: 10^{7} \mathrm{cfu} / \mathrm{ml} ; \mathrm{K}_{2}: 10^{8} \mathrm{cfu} / \mathrm{ml} ; \mathrm{K}_{3}: 10^{9} \mathrm{cfu} / \mathrm{ml}$. Hasil penelitian ini menunjukkan bahwa perlakuan benih menggunakan rizobakteri jenis Necercia sp dengan kerapatan inokulum $10^{8} \mathrm{cfu} / \mathrm{ml}$ nyata meningkatkan vigor benih pada tolok ukur indeks vigor yaitu $40 \%$ dan Pseudomonas capacia dengan kerapatan inokulum $10^{9} \mathrm{cfu} / \mathrm{ml}$ juga merupakan kombinasi perlakuan terbaik dalam meningkatkan berat kering kecambah normal yaitu 69,33 mg.
\end{abstract}

Kata kunci : Biological seed treatment, rizobakteri, kerapatan inokulum, benih kadaluarsa.

\begin{abstract}
Biological seed treatment is one of the seed treatment using microorganisms such as plant growthpromoting rhizobacteria (PGPR). This study aims to determine the type of rhizobacteria and inoculum density that can increase the viability and vigor of expired chili seeds. This research uses Completely Randomized Design (CRD) factorial pattern with 2 factors and 3 replications. The first factor is the type of rhizobacteria (R) consists of five levels, namely $\mathrm{R}_{1}$ : Necercia sp; $\mathrm{R}_{2}$ : Bacillus polymixa; $\mathrm{R}_{3}$ : Actinobacillus suis; $\mathrm{R}_{4}$ : Azotobacter $\mathrm{sp} ; \mathrm{R}_{5}$ : Pseudomonas capacia. The second factor is the density of rhizobacteria inoculum consisting of three levels namely $\mathrm{K}_{1}: 10^{7} \mathrm{cfu} / \mathrm{ml} ; \mathrm{K}_{2}: 10^{8} \mathrm{cfu} / \mathrm{ml} ; \mathrm{K}_{3}: 10^{9} \mathrm{cfu} / \mathrm{ml}$. The results of this study showed that the seed treatment using the Necercia sp-type rizobacteria with $10^{8} \mathrm{cfu} / \mathrm{ml}$ inoculum density significantly increased the seed vigor on the vigor index benchmark of $40 \%$ and Pseudomonas capacia with $10^{9} \mathrm{cfu} / \mathrm{ml}$ inoculum density was also the best treatment combination in increasing dry weight normal sprout is $69,33 \mathrm{mg}$.
\end{abstract}

Key words: Biological seed treatment, rhizobacteria, inoculum density, expired seeds.

\section{PENDAHULUAN}

Kemunduran benih adalah menurunnya kualitas, daya kecambah dan kekuatan tumbuh benih setelah mencapai kualitas maksimum yang diakibatkan oleh faktor-faktor lingkungan yang mengakibatkan perubahan didalam benih baik fisik, fisiologis maupun kimiawi (Justice dan Bass, 2002). Proses kemunduran benih adalah proses yang tidak dapat dicegah dan tidak dapat kembali namun dapat diperlambat dengan perlakuan tertentu. Benih yang mengalami kemunduran masih mungkin digunakan sebagai bahan tanam dengan cara memberikan suatu perlakuan sebelum tanam atau disebut dengan invigorasi.

Biological seed treatment atau biopriming adalah suatu teknik perlakuan benih yang mengintegrasikan satu atau lebih mikroorganisme dan aspek fisiologis yang bermanfaat bagi benih untuk meningkatkan viabilitas dan vigor benih, melindungi benih serta mendorong pertumbuhan dan perkembangan tanaman. Salah satu mikroorganisme yang dapat meningkatkan perkecambahan dan pertumbuhan tanaman adalah rizobakteri. Rizobakteri pemacu pertumbuhan adalah bakteri yang hidup dan berkembang di tanah dan bila diaplikasikan pada tanah atau benih dapat mendorong pertumbuhan tanaman dan mengurangi 
serangan patogen terbawa tanah. Egamberdiyeva (2007) menyatakan bahwa keuntungan perlakuan benih secara hayati selain meningkatkan perkecambahan benih, pertumbuhan dan produksi tanaman, juga dapat mengurangi biaya produksi dan meminimalkan kerusakan lingkungan akibat polusi penggunaan bahan kimia.

Plant growth promoting rhizobacteria (PGPR) dapat mempengaruhi pertumbuhan tanaman baik secara langsung maupun tidak langsung melalui fiksasi nitrogen, produksi siderofor, mensintesis fitohormon, termasuk auksin, sitokinin dan giberelin serta mensintesis ACC-deaminase (Antoun et al., 2006).

Selain jenis rizobakteri yang digunakan, kerapatan inokulum rizobakteri yang diaplikasikan pada benih menunjukkan tingkat viabilitas dan vigor yang berbeda. Kajian mengenai kerapatan inokulum perlu dilakukan karena setiap isolat memiliki potensi yang berbeda dalam meningkatkan perkecambahan benih.

Hasil penelitian Humaira (2017) menunjukkan bahwa perlakuan benih menggunakan rizobakteri jenis Necercia sp. dengan kerapatan inokulum $10^{9} \mathrm{cfu} / \mathrm{ml}$ dapat meningkatkan daya kecambah benih sebesar $89 \%$ serta memiliki waktu yang lebih cepat perkecambahan pada benih tomat. Sutariati et al. (2006) juga menyatakan bahwa perlakuan benih menggunakan isolat Bacillus sp, Pseudomonas sp, dan Serratia sp dengan cara direndam selama 24 jam pada kerapatan inokulum $10^{9} \mathrm{cfu} / \mathrm{ml}$ dapat meningkatkan perkecambahan benih, sementara diantara isolat Bacillus sp., Pseudomonas sp., dan Serratia sp. yang digunakan, isolat Bacillus polymixa dapat meningkatkan daya kecambah sebesar $88 \%$ dan memberikan dampak terbaik terhadap berbagai peubah perkecambahan benih cabai lainnya. Sedangkan penelitian Prakoso (2009) melaporkan bahwa perlakuan rizobakteri jenis Pseudomonas fluorescens dengan cara direndam selama 12 jam pada kerapatan inokulum $10^{7}$ $\mathrm{cfu} / \mathrm{ml}$ pada benih jarak pagar hanya dapat berkecambah sebesar $20 \%$.

Berdasarkan uraian di atas maka perlu dilakukan penelitian tentang jenis rizobakteri dan tingkat kerapatan inokulum terhadap peningkatan viabilitas dan vigor benih cabai kadaluarsa.

\section{METODE PENELITIAN}

\section{Tempat dan Waktu Penelitian}

Penelitian dilaksanakan di Laboratorium Ilmu dan Teknologi Benih Program Studi Agroteknologi Fakultas Pertanian Universitas Syiah Kuala Darussalam Banda Aceh pada bulan Juli sampai Oktober 2017.

\section{Alat dan Bahan Penelitian}

Alat yang digunakan dalam penelitian ini adalah autoclave, timbangan analitik, spektrofotometer Spectronic 20D + Laminar Air Flow Cabinet, oven listrik, ruang inkubasi, lampu bunsen, cawan petri, tabung reaksi, erlenmeyer, gelas ukur, kompor gas, spatula, germinator, aerator, jarum ose, pinset, hand sprayer listrik, pisau, saringan, bak perkecambahan, kamera, ayakan tanah dan alat tulis. Bahan yang digunakan pada penelitian ini adalah benih cabai merah kadaluarsa varietas Tanaka F1 dan telah mengalami kadaluarsa pada bulan Februari 2016 dengan daya kecambah awal setelah uji pendahuluan 56\%, Rizobakteri Pemacu Pertumbuhan Tanaman (RPPT) koleksi Laboratorium Ilmu dan Teknologi Benih Program Studi Agroteknologi Fakultas Pertanian Universitas Syiah Kuala yang terdiri dari lima jenis yaitu Necercia sp., Bacillus polymixa, Actinobacillus suis, Azotobacter sp. dan Pseudomonas capacia, plastic wrap, aluminium foil, kentang, agar powder, dextrose, alkohol 95\%, aquades, tanah, pupuk kandang, spritus.

$\overline{\text { Perlakuan Rizobakteri Pemacu Pertumbuhan Tanaman (RPPT) dengan Beberapa Tingkat Kerapatan Inokulum }}$ Rizobakteri Terhadap Viabilitas dan Vigor Benih Cabai Merah Kadaluarsa (Capsicum annuum L.) (Dayang 


\section{Rancangan Penelitian}

Penelitian ini menggunakan Rancangan Acak Lengkap (RAL) pola faktorial dengan 2 faktor dan 3 ulangan. Faktor pertama yaitu jenis rizobakteri terdiri lima taraf yaitu Necercia sp. $\left(\mathrm{R}_{1}\right)$, Bacillus polymixa $\left(\mathrm{R}_{2}\right)$, Actinobacillus suis $\left(\mathrm{R}_{3}\right)$, Azotobacter $\mathrm{sp} .\left(\mathrm{R}_{4}\right)$ dan Pseudomonas capacia $\left(\mathrm{R}_{5}\right)$. Faktor kedua yaitu kerapatan inokulum rizobakteri dengan tiga taraf yaitu $10^{7} \mathrm{cfu} / \mathrm{ml}\left(\mathrm{K}_{1}\right), 10^{8} \mathrm{cfu} / \mathrm{ml}\left(\mathrm{K}_{2}\right)$, dan $10^{9} \mathrm{cfu} / \mathrm{ml}\left(\mathrm{K}_{3}\right)$. Dengan demikian terdapat 15 kombinasi perlakuan.

\section{Analisis data}

Untuk menguji pengaruh dari setiap faktor dan interaksi antar faktor terhadap parameter analisis, dilakukan analisis statistik dengan menggunakan ANOVA (Analysis of varians). Apabila perlakuan yang diberikan menunjukkan pengaruh terhadap parameter yang diuji, maka dilakukan uji lanjut BNJ (Beda Nyata Jujur).

\section{Prosedur Penelitian \\ Persiapan Benih}

Benih cabai kadaluarsa dipilih mutu fisiknya yang baik dengan cara direndam dalam air selama lima menit. Kemudian benih cabai tersebut dikering anginkan di dalam Laminar Air Flow Cabinet selama satu jam dan siap untuk digunakan.

\section{Persiapan Media PDA (Potato Dextrose Agar)}

Kentang dikupas terlebih dahulu lalu dicuci dan diiris tipis kemudian ditimbang sebanyak $200 \mathrm{~g}$. Kentang direbus dengan aquades sebanyak $500 \mathrm{ml}$ hingga mendidih. Disaring dan sari kentangnya diambil, lalu aquades steril dididihkan sebanyak $500 \mathrm{ml}$ bersama agar sebanyak $15 \mathrm{~g}$ dan dextrose sebanyak $15 \mathrm{~g}$, kedua bahan diaduk hingga larut. Jika sudah larut dengan baik, larutan agar disatukan dengan ekstrak kentang yang telah disaring di dalam gelas ukur berukuran 1 L. Larutan campuran agar dan kentang dimasukkan ke dalam erlenmeyer dan ditutup dengan plastik tahan panas dan aluminium foil lalu diikat dengan karet hingga benar-benar kedap udara. Kemudian larutan PDA disterilisasi menggunakan autoclave selama 15 menit pada suhu $121{ }^{\circ} \mathrm{C}$. Setelah disterilisasi, larutan PDA didinginkan hingga suhunya turun menjadi hangat kuku atau sekitar $40{ }^{\circ} \mathrm{C}$ dan siap dituang ke dalam cawan petri sebanyak $10 \mathrm{ml}$. Larutan PDA yang telah dituang, disimpan di dalam Laminar Air Flow Cabinet agar tidak terkontaminasi. Setelah PDA memadat, media PDA siap digunakan.

\section{Persiapan Isolat Rizobakteri Pemacu Pertumbuhan Tanaman}

Rizobakteri dikembangbiakkan pada media PDA dan diinkubasi selama 48 jam hingga koloni rizobakteri tumbuh. Koloni rizobakteri yang tumbuh disuspensi dalam aquades steril $50 \mathrm{ml}$. Larutan suspensi yang telah siap, kerapatan inokulumnya dihitung menggunakan spektrofotometer hingga didapatkan beberapa kerapatan inokulum yaitu $10^{7}, 10^{8}, 10^{9} \mathrm{cfu} / \mathrm{ml}$.

\section{Perlakuan Benih dengan Rizobakteri}

Sebanyak 25 butir benih yang siap diberi perlakuan, direndam selama 24 jam dalam suspensi masing-masing isolat rizobakteri $(100 \mathrm{ml})$ dengan berbagai tingkat kerapatan sesuai perlakuan telah diketahui pada suhu $26{ }^{\circ} \mathrm{C}$. Setelah perlakuan, benih kembali dikering anginkan dalam LAFC selama satu jam dan siap untuk dikecambahkan. 


\section{Pengecambahan Benih}

Benih yang telah diberi perlakuan rizobakteri selanjutnya dikecambahkan dalam wadah box plastik berukuran $27 \mathrm{~cm} \times 56 \mathrm{~cm}$ x $5 \mathrm{~cm}$ (panjang x lebar x tinggi) berisi tanah dan pupuk kandang dengan perbandingan 2:1 sebagai media perkecambahan. Sebelumnya, tanah dan pupuk kandang diayak menggunakan ayakan ukuran 5 mesh lalu disterilkan menggunakan autoclave pada suhu $120{ }^{\circ} \mathrm{C}$ selama 30 menit. Setiap perlakuan ditanam 25 benih dan diulang tiga kali.

\section{Pengamatan}

Parameter yang diamati pada penelitian ini meliputi potensi tumbuh maksimum (PTM), daya berkecambah (DB), keserempakan tumbuh $\left(\mathrm{K}_{\mathrm{ST}}\right.$ ), indeks vigor (IV), kecepatan tumbuh relatif $\left(\mathrm{K}_{\mathrm{CT}}-\mathrm{R}\right)$, waktu yang dibutuhkan untuk mencapai $50 \%$ kecambah total relatif, berat basah kecambah normal (BBKN), dan berat kering kecambah normal (BKKN).

\section{HASIL DAN PEMBAHASAN}

\section{Kemampuan Rizobakteri dalam Meningkatkan Viabilitas dan Vigor Benih Cabai Merah Kadaluarsa}

Hasil analisis ragam menunjukkan bahwa perlakuan rizobakteri berpengaruh sangat nyata terhadap tolok ukur potensi tumbuh maksimum (PTM), daya berkecambah (DB), keserempakan tumbuh $\left(\mathrm{K}_{\mathrm{ST}}\right)$, berat basah kecambah normal (BBKN) dan berat kering kecambah normal (BKKN) dan berpengaruh nyata pada tolok ukur indeks vigor (IV) dan kecepatan tumbuh relatif $\left(\mathrm{K}_{\mathrm{CT}}-\mathrm{R}\right)$ namun tidak berpengaruh nyata pada tolok ukur waktu yang dibutuhkan untuk mencapai $50 \%$ kecambah total $\left(\mathrm{T}_{50}\right)$. Rata-rata nilai PTM, DB, $\mathrm{K}_{\mathrm{ST}}$, $\mathrm{IV}, \mathrm{K}_{\mathrm{CT}}-\mathrm{R}, \mathrm{T}_{50}, \mathrm{BBKN}$ dan $\mathrm{BKKN}$ benih cabai kadaluarsa hasil perlakuan benih menggunakan RPPT dapat dilihat pada Tabel 1.

Tabel 1. Rata-rata potensi tumbuh maksimum, daya berkecambah, keserempakan tumbuh, indeks vigor, kecepatan tumbuh relatif, waktu yang dibutuhkan untuk mencapai 50\% kecambah total relatif, berat basah kecambah normal dan berat kering kecambah normal benih cabai kadaluarsa hasil perlakuan benih menggunakan rizobakteri pemacu pertumbuhan tanaman

\begin{tabular}{lcccccccc}
\hline \multirow{2}{*}{$\begin{array}{c}\text { Jenis } \\
\text { Rizobakteri }\end{array}$} & $\begin{array}{c}\text { PTM } \\
(\%)\end{array}$ & $\begin{array}{c}\mathrm{DB} \\
(\%)\end{array}$ & $\begin{array}{c}\mathrm{K}_{\mathrm{ST}} \\
(\%)\end{array}$ & $\begin{array}{c}\mathrm{IV} \\
(\%)\end{array}$ & $\begin{array}{c}\mathrm{K}_{\mathrm{CT}}-\mathrm{R} \\
(\%)\end{array}$ & $\begin{array}{c}\mathrm{T}_{50} \\
(\text { hari })\end{array}$ & $\begin{array}{c}\mathrm{BBKN} \\
(\mathrm{mg})\end{array}$ & $\begin{array}{c}\mathrm{BKKN} \\
(\mathrm{mg})\end{array}$ \\
\hline Necercia sp & $87,11 \mathrm{ab}$ & $81,33 \mathrm{ab}$ & $69,33 \mathrm{~b}$ & $31,56 \mathrm{~b}$ & $75,72 \mathrm{~b}$ & 6,80 & $447 \mathrm{ab}$ & $49,33 \mathrm{a}$ \\
B. polymixa & $81,33 \mathrm{a}$ & $73,33 \mathrm{a}$ & $56,89 \mathrm{a}$ & $24,45 \mathrm{a}$ & $63,95 \mathrm{a}$ & 6,52 & $407 \mathrm{a}$ & $52,55 \mathrm{ab}$ \\
A. suis & $83,55 \mathrm{a}$ & $77,78 \mathrm{a}$ & $55,11 \mathrm{a}$ & $28,44 \mathrm{ab}$ & $69,95 \mathrm{ab}$ & 6,48 & $413 \mathrm{a}$ & $48,67 \mathrm{a}$ \\
Azotobacter sp & $83,11 \mathrm{a}$ & $79,56 \mathrm{ab}$ & $54,22 \mathrm{a}$ & $28,89 \mathrm{ab}$ & $69,01 \mathrm{ab}$ & 6,86 & $453 \mathrm{ab}$ & $52,67 \mathrm{ab}$ \\
P. capacia & $93,33 \mathrm{~b}$ & $88,89 \mathrm{~b}$ & $57,78 \mathrm{ab}$ & $30,22 \mathrm{ab}$ & $74,72 \mathrm{~b}$ & 6,57 & $503 \mathrm{~b}$ & $60,67 \mathrm{~b}$ \\
\hline BNJ 0,05 & 9,29 & 10,34 & 12,14 & 6,26 & 9,87 & - & 62,42 & 9,95
\end{tabular}

Keterangan: Angka yang diikuti oleh huruf yang sama pada kolom yang sama tidak berbeda nyata berdasarkan uji Beda Nyata Jujur (BNJ) pada $\alpha=0,05$. PTM: potensi tumbuh maksimum; DB: daya berkecambah; $\mathrm{K}_{\mathrm{ST}}$ : keserempakan tumbuh; IV : indeks vigor; $\mathrm{K}_{\mathrm{CT}}-\mathrm{R}$ : kecepatan tumbuh relatif; $\mathrm{T}_{50}$ : waktu yang dibutuhkan untuk mencapai $50 \%$ perkecambahan total relatif; BBKN: Berat Basah Kecambah Normal ; BKKN: Berat Kering Kecambah Normal. 
Hasil penelitian menunjukkan bahwa jenis rizobakteri yang digunakan berperan sebagai agen pemacu pertumbuhan sehingga menghasilkan benih berkecambah lebih baik, cepat, serempak, dan seragam dibandingkan dengan benih yang tidak diberi perlakuan rizobakteri. Diantara perlakuan benih menggunakan isolat rizobakteri Necercia sp., B. polymixa, A. suis, Azotobacter sp. dan $P$. capacia, perlakuan terbaik didapat pada jenis $P$. capacia. Jenis bakteri ini dapat meningkatkan nilai pada tolok ukur potensi tumbuh maksimum, daya berkecambah, kecepatan tumbuh relatif, berat basah kecambah normal dan berat kering kecambah normal. Sedangkan pada tolok ukur keserempakan tumbuh, indeks vigor perlakuan terbaik ditunjukkan oleh perlakuan rizobakteri jenis Necercia sp. Kelompok rizobakteri $P$. capacia dan Necercia sp diyakini sebagai rizobakteri pemacu pertumbuhan tanaman yang efektif meningkatkan pertumbuhan karena memiliki kemampuan memproduksi auksin dengan konsentrasi lebih tinggi dari pada Bacillus (Reetha et al., 2014). Berbagai asam organik yang diproduksi oleh rizobakteri sebagai pemacu pertumbuhan tanaman dari kelompok Pseudomonas spp. adalah asam glukonat, asam organik 2-ketoglukonat, asam laktat, isobutirat dan asam asetat (Kloepper, 2003).

Hasil penelitian ini sesuai dengan penelitian sebelumnya bahwa perlakuan benih menggunakan rizobakteri jenis Pseudomonas sp dan Necercia sp dapat meningkatkan viabilitas dan vigor benih secara nyata dan lebih baik dibandingkan benih yang tidak diaplikasikan rizobakteri (Sutariati et al., 2006; Humaira, 2017). Perlakuan benih menggunakan rizobakteri jenis $P$. capacia memberikan dampak positif terhadap tanaman pada fase perkecambahan benih dan pertumbuhan bibit tanaman cabai pada berbagai tolok ukur yang diamati (Mardiah et al., 2016).

Peningkatan viabilitas dan vigor benih cabai kadaluarsa disebabkan adanya inkorporasi rizobakteri pada benih, kemampuannya memfiksasi nitrogen, melarutkan fosfat dan menghasilkan hormon pemacu pertumbuhan seperti auksin, sitokinin dan giberelin dalam mekanismenya sebagai agen pemacu pertumbuhan dan produksi tanaman (Egamberdiyeva, 2007; Bae et al., 2007). Rizobakteri secara kompetitif mengkolonisasi area rizosfer dan memanfaatkan eksudat yang dikeluarkan oleh akar tanaman. Kemampuan mengkolonisasi area rizosfer dipengaruhi oleh konsentrasi asam amino triptofan yang tinggi di daerah sistem perakaran (Kravchenko et al., 2005).

\section{Pengaruh Kerapatan Inokulum Rizobakteri Terhadap Viabilitas dan Vigor Benih Cabai Merah Kadaluarsa}

Hasil analisis ragam menunjukkan bahwa perlakuan kerapatan inokulum rizobakteri berpengaruh sangat nyata terhadap tolok ukur BBKN dan BKKN serta berpengaruh nyata terhadap tolok ukur PTM, DB, IV dan $\mathrm{K}_{\mathrm{CT}}-\mathrm{R}$ akan tetapi tidak berpengaruh nyata terhadap tolok ukur $\mathrm{K}_{\mathrm{ST}}$ dan $\mathrm{T}_{50}$. Pada interaksi antara perlakuan rizobakteri dan kerapatan inokulum rizobakteri berpengaruh sangat nyata terhadap tolok ukur IV dan BKKN, akan tetapi tidak berpengaruh nyata terhadap tolok ukur lainnya. Rata-rata nilai PTM, DB, $\mathrm{K}_{\mathrm{ST}}, \mathrm{IV}, \mathrm{K}_{\mathrm{CT}}-\mathrm{R}$, $\mathrm{T}_{50}$, BBKN dan BKKN benih cabai kadaluarsa hasil perlakuan benih menggunakan kerapatan inokulum rizobakteri dapat dilihat pada Tabel 2. 
Tabel 2. Rata-rata potensi tumbuh maksimum, daya berkecambah, keserempakan tumbuh indeks vigor, kecepatan tumbuh relatif, waktu yang dibutuhkan untuk mencapai $50 \%$ perkecambahan total relatif, berat basah kecambah normal dan berat kering kecambah normal hasil perlakuan kerapatan inokulum rizobakteri

\begin{tabular}{ccccccccc}
\hline $\begin{array}{c}\text { Kerapatan } \\
\text { Inokulum }\end{array}$ & \multicolumn{7}{c}{ Tolok Ukur Viabilitas dan Vigor Benih yang Diamati } \\
\cline { 2 - 9 } $\begin{array}{c}\text { Rizobakteri } \\
(\mathrm{cfu} / \mathrm{ml})\end{array}$ & $\begin{array}{c}\mathrm{PTM} \\
(\%)\end{array}$ & $\begin{array}{c}\mathrm{DB} \\
(\%)\end{array}$ & $\begin{array}{c}\mathrm{K}_{\mathrm{ST}} \\
(\%)\end{array}$ & $\begin{array}{c}\mathrm{IV} \\
(\%)\end{array}$ & $\begin{array}{c}\mathrm{K}_{\mathrm{CT}} \mathrm{R} \\
(\%)\end{array}$ & $\begin{array}{c}\mathrm{T}_{50} \\
(\text { hari })\end{array}$ & $\begin{array}{c}\text { BBKN } \\
(\mathrm{mg})\end{array}$ & $\begin{array}{c}\text { BKKN } \\
(\mathrm{mg})\end{array}$ \\
\hline $10^{7}$ & $81,87 \mathrm{a}$ & $75,73 \mathrm{a}$ & 54,67 & $26,40 \mathrm{a}$ & $66,23 \mathrm{a}$ & 6,66 & $390 \mathrm{a}$ & $43,66 \mathrm{a}$ \\
$10^{8}$ & $86,13 \mathrm{ab}$ & $80,27 \mathrm{ab}$ & 60,27 & $30,67 \mathrm{~b}$ & $71,11 \mathrm{ab}$ & 6,62 & $450 \mathrm{~b}$ & $57,46 \mathrm{~b}$ \\
$10^{9}$ & $89,07 \mathrm{~b}$ & $84,53 \mathrm{~b}$ & 61,07 & $29,07 \mathrm{ab}$ & $74,67 \mathrm{~b}$ & 6,66 & $496 \mathrm{c}$ & $57,20 \mathrm{~b}$ \\
\hline BNJ 0,05 & 6,13 & 6,82 & - & 13,78 & 6,51 & - & 41,16 & 6,56 \\
\hline
\end{tabular}

Keterangan: Angka yang diikuti oleh huruf yang sama pada kolom yang sama tidak berbeda nyata berdasarkan uji Beda Nyata Jujur (BNJ) pada $\alpha=0,05$. PTM: potensi tumbuh maksimum; DB: daya berkecambah; $10^{7} \mathrm{cfu} / \mathrm{ml}, 10^{8} \mathrm{cfu} / \mathrm{ml}, 10^{9} \mathrm{cfu} / \mathrm{ml}$ : Kerapatan inokulum rizobakteri; $\mathrm{K}_{\mathrm{ST}}$ : keserempakan tumbuh; IV: indeks vigor; $\mathrm{K}_{\mathrm{CT}} \mathrm{R}$ : kecepatan tumbuh relatif; $\mathrm{T}_{50}$ : waktu yang dibutuhkan untuk mencapai 50\% perkecambahan total relatif; BBKN: Berat Basah Kecambah Normal; BKKN: Berat Kering Kecambah Normal.

Tabel 2 menunjukkan bahwa perlakuan kerapatan inokulum rizobakteri yang terbaik adalah $10^{9} \mathrm{cfu} / \mathrm{ml}$ dan dapat diberikan sebagai perlakuan perkecambahan benih untuk meningkatkan viabilitas dan vigor benih cabai merah yang sudah mengalami kemunduran (kadaluarsa). Berdasarkan tolok ukur viabilitas dan vigor yang diamati berdasarkan PTM, $\mathrm{DB}, \mathrm{K}_{\mathrm{ST}}, \mathrm{IV}, \mathrm{K}_{\mathrm{CT}}-\mathrm{R}, \mathrm{BBKN}$ dan $\mathrm{BKKN}$ secara nyata menunjukkan peningkatan seiring dengan meningkatnya kerapatan inokulum yang digunakan. Penurunan kerapatan inokulum rizobakteri dibawah $10^{8} \mathrm{cfu} / \mathrm{ml}$ berdampak negatif terhadap semua nilai tolok ukur viabilitas dan vigor benih yang diamati. Nilai tolok ukur PT, DB, $\mathrm{K}_{\mathrm{ST}}, \mathrm{IV}, \mathrm{K}_{\mathrm{CT}}-\mathrm{R}, \mathrm{BBKN}$ dan BKKN secara signifikan terjadi penurunan pada benih hasil perlakuan dengan kerapatan inokulum rizobakteri $10^{7} \mathrm{cfu} / \mathrm{ml}$ (Tabel 2). Kerapatan inokulum $10^{9} \mathrm{cfu} / \mathrm{ml}$ diyakini berpengaruh pada jumlah inokulum potensial dan keefektifan rizobakteri dalam menginfeksi benih, mensintesis serta mengatur konsentrasi berbagai zat pengatur tumbuh (fitohormon) seperti auksin, sitokinin dan giberelin yang dibutuhkan oleh benih untuk berkecambah. Kebutuhan hormon tumbuh untuk mempercepat proses perkecambahan benih cabai kadaluarsa kemungkinan besar sudah tercukupi dengan penggunaan kerapatan inokulum $10^{9} \mathrm{cfu} / \mathrm{ml}$. Ali (2015) menyatakan bahwa indikasi produksi IAA oleh bakteri tergantung pada kerapatan dan jenis bakteri yang melakukannya. Hal ini sesuai dengan mekanisme kerja rizobakteri yang membutuhkan kerapatan inokulum tertentu untuk berperan sebagai agen pemacu pertumbuhan tanaman. Hormon tumbuh terutama IAA yang dihasilkan dari metabolisme rizobakteri pemacu pertumbuhan tanaman sangat dibutuhkan dalam mempercepat proses perkecambahan benih yang berfungsi meningkatkan perkembangan sel, absisi, mobilisasi karbohidrat selama perkecambahan, merangsang pembentukan dan pertumbuhan akar (Djamhuri, 2011).

Pengaruh negatif dari penggunaan kerapatan inokulum rizobakteri yang rendah dalam penelitian ini $\left(<10^{8} \mathrm{cfu} / \mathrm{ml}\right)$ terhadap nilai viabilitas dan vigor benih berhubungan dengan mekanisme kerja rizobakteri dalam menghasilkan senyawa dan fitohormon yang dibutuhkan oleh benih. Hasil penelitian Prakoso (2009) melaporkan bahwa perlakuan rizobakteri jenis 
Pseudomonas sp dengan cara direndam selama 12 jam pada kerapatan inokulum $10^{7} \mathrm{cfu} / \mathrm{ml}$ pada benih jarak pagar hanya dapat berkecambah sebesar 20\%. Berdasarkan hasil penelitian ini dapat dikatakan bahwa rizobakteri akan berperan efektif sebagai pemacu pertumbuhan tanaman tergantung pada kerapatan inokulumnya.

\section{Interaksi Antara Rizobakteri dan Kerapatan Inokulum Rizobakteri Terhadap Viabilitas dan Vigor Benih Cabai Merah Kadaluarsa}

Hubungan interaksi antara jenis rizobakteri dan kerapatan inokulum rizobakteri menunjukkan pengaruh sangat nyata pada tolok ukur indeks vigor dan berat kering kecambah normal. Nilai indeks vigor dan berat kering kecambah normal pada masing-masing jenis rizobakteri dengan taraf kerapatan inokulum rizobakteri disajikan pada Tabel 3 dan 4.

Tabel 3. Rata-rata indeks vigor benih cabai (\%) untuk tiap jenis rizobakteri pada berbagai kerapatan inokulum rizobakteri

\begin{tabular}{lccc}
\hline \multirow{2}{*}{ Jenis Rizobakteri } & \multicolumn{3}{c}{ Kerapatan Inokulum Rizobakteri } \\
\cline { 2 - 4 } & $10^{7} \mathrm{cfu} / \mathrm{ml}$ & $10^{8} \mathrm{cfu} / \mathrm{ml}$ & $10^{9} \mathrm{cfu} / \mathrm{ml}$ \\
\hline Necercia $\mathrm{sp}$ & $30,67 \mathrm{ABb}$ & $40,00 \mathrm{Bb}$ & $24,00 \mathrm{Aa}$ \\
B. polymixa & $16,00 \mathrm{Aa}$ & $26,67 \mathrm{ABab}$ & $30,67 \mathrm{Ba}$ \\
A. suis & $28,00 \mathrm{Aab}$ & $25,33 \mathrm{Aa}$ & $32,00 \mathrm{Aa}$ \\
Azotobacter sp & $28,00 \mathrm{Aab}$ & $33,33 \mathrm{Aab}$ & $25,33 \mathrm{Aa}$ \\
P. capacia & $29,33 \mathrm{Aab}$ & $28,00 \mathrm{Aab}$ & $33,33 \mathrm{Aa}$ \\
\hline
\end{tabular}

BNJ 0,05 13,78

Keterangan: Angka yang diikuti oleh huruf yang sama pada kolom yang sama tidak berbeda nyata berdasarkan uji Beda Nyata Jujur (BNJ) pada $\alpha=0,05$ (huruf besar dibaca horizontal, huruf kecil dibaca vertikal); $10^{7} \mathrm{cfu} / \mathrm{ml}, 10^{8} \mathrm{cfu} / \mathrm{ml}, 10^{9} \mathrm{cfu} / \mathrm{ml}:$ Kerapatan inokulum rizobakteri

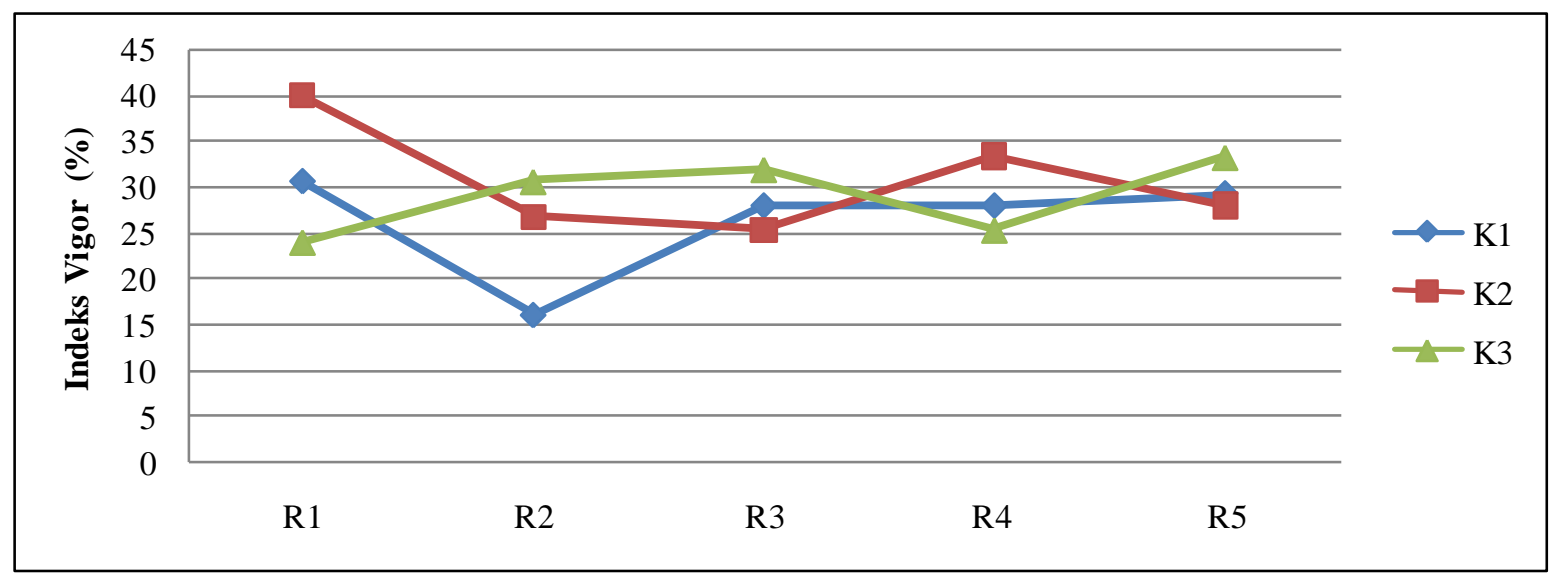

Keterangan : $\mathrm{R}_{1}$ : Necercia $\mathrm{sp}, \mathrm{R}_{2}$ : Bacillus polymixa, $\mathrm{R}_{3}$ : Actinobacillus suis, $\mathrm{R}_{4}$ : Azotobacter $\mathrm{sp}, \mathrm{R}_{5}$ : Pseudomonas capacia; $\mathrm{K}_{1}: 10^{7} \mathrm{cfu} / \mathrm{ml}, \mathrm{K}_{2}: 10^{8} \mathrm{cfu} / \mathrm{ml}, \mathrm{K}_{3}: 10^{9} \mathrm{cfu} / \mathrm{ml}$.

Tabel 3 menunjukkan bahwa diantara kelima jenis rizobakteri yang diuji pada ketiga kerapatan inokulum rizobakteri, perlakuan jenis rizobakteri Necercia sp dengan kerapatan inokulum $10^{8} \mathrm{cfu} / \mathrm{ml}$ menunjukkan nilai indeks vigor tertinggi yaitu 40,00\% yang berbeda nyata dengan kerapatan inokulum $10^{9} \mathrm{cfu} / \mathrm{ml}$, namun berbeda tidak nyata dengan $10^{7} \mathrm{cfu} / \mathrm{ml}$. 
Tabel 4.Rata-rata berat kering kecambah normal benih cabai (mg) untuk tiap jenis rizobakteri pada berbagai kerapatan inokulum rizobakteri

\begin{tabular}{lccc}
\hline \multirow{2}{*}{ Jenis Rizobakteri } & \multicolumn{3}{c}{ Kerapatan Inokulum Rizobakteri } \\
\cline { 2 - 4 } & $10^{7} \mathrm{cfu} / \mathrm{ml}$ & $10^{8} \mathrm{cfu} / \mathrm{ml}$ & $10^{9} \mathrm{cfu} / \mathrm{ml}$ \\
\hline Necercia sp & $40,67 \mathrm{Aab}$ & $67,67 \mathrm{Ba}$ & $39,00 \mathrm{Aa}$ \\
B. polymixa & $52,33 \mathrm{Aab}$ & $47,33 \mathrm{Aa}$ & $58,00 \mathrm{Aab}$ \\
A. suis & $32,33 \mathrm{Aa}$ & $51,67 \mathrm{ABa}$ & $61,63 \mathrm{Bb}$ \\
Azotobacter sp & $37,67 \mathrm{Aab}$ & $62,33 \mathrm{Ba}$ & $58,00 \mathrm{ABab}$ \\
P. capacia & $55,20 \mathrm{Ab}$ & $58,33 \mathrm{Aa}$ & $69,33 \mathrm{Ab}$ \\
\hline BNJ 0,05 & & 21,90
\end{tabular}

Keterangan: Angka yang diikuti oleh huruf yang sama pada kolom yang sama tidak berbeda nyata berdasarkan uji Beda Nyata Jujur (BNJ) pada $\alpha=0,05$ (huruf besar dibaca horizontal, huruf kecil dibaca vertikal). $10^{7} \mathrm{cfu} / \mathrm{ml}, 10^{8} \mathrm{cfu} / \mathrm{ml}, 10^{9} \mathrm{cfu} / \mathrm{ml}$ : Kerapatan inokulum rizobakteri.

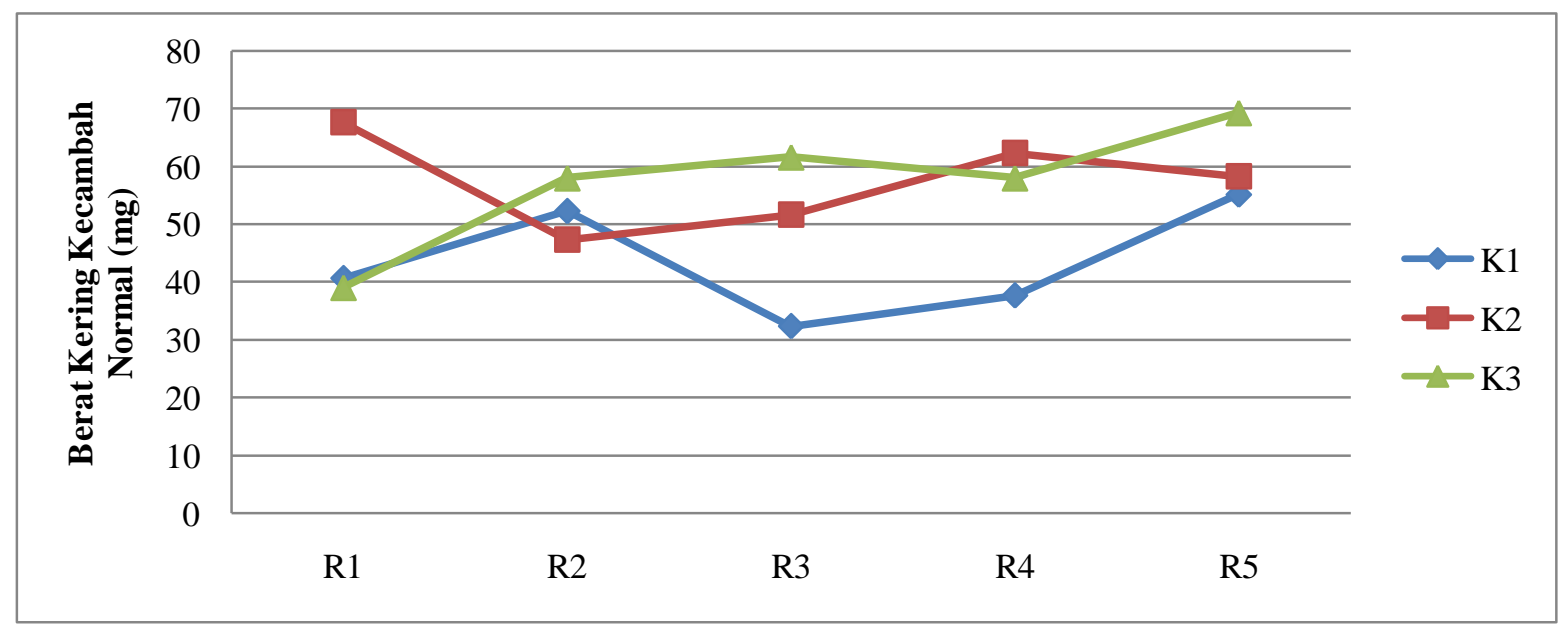

Keterangan : $\mathrm{R}_{1}$ : Necercia $\mathrm{sp}, \mathrm{R}_{2}$ : Bacillus polymixa, $\mathrm{R}_{3}$ : Actinobacillus suis, $\mathrm{R}_{4}$ : Azotobacter $\mathrm{sp}, \mathrm{R}_{5}$ : Pseudomonas capacia; $\mathrm{K}_{1}: 10^{7} \mathrm{cfu} / \mathrm{ml}, \mathrm{K}_{2}: 10^{8} \mathrm{cfu} / \mathrm{ml}, \mathrm{K}_{3}: 10^{9} \mathrm{cfu} / \mathrm{ml}$.

Tabel 4 menunjukkan bahwa perlakuan jenis rizobakteri $P$. capacia dengan kerapatan inokulum $10^{9} \mathrm{cfu} / \mathrm{ml}$ menunjukkan nilai berat kering kecambah normal tertinggi yaitu $69,33 \%$ yang berbeda tidak nyata dengan perlakuan kerapatan inokulum lainnya.

Berdasarkan hasil penelitian dapat dikatakan bahwa jenis rizobakteri Necercia sp dengan kerapatan inokulum $10^{8} \mathrm{cfu} / \mathrm{ml}$ dan $P$. capacia dengan kerapatan inokulum $10^{9} \mathrm{cfu} / \mathrm{ml}$ menunjukkan kemampuan yang lebih baik dalam meningkatkan perkecambahan benih cabai merah kadaluarsa dibandingkan dengan isolat rizobakteri lainnya dan kerapatan inokulum lainnya. Hal ini berpengaruh pada efektivitasnya dalam memproduksi fitohormon seperti IAA, giberelin dan sitokinin, selain kemampuannya melarutkan fosfat dan memfiksasi nitrogen sebagai agen pemacu pertumbuhan tanaman. Hasil penelitian Iqbal dan Hasnain (2013) menyatakan bahwa produksi metabolit sekunder dari Pseudomonas sp adalah auksin dan jenis rizobakteri ini mampu memproduksi auksin dengan konsentrasi lebih tinggi.

Hal ini juga sama dengan hasil penelitian sebelumnya bahwa perbedaan kemampuan memproduksi IAA dari berbagai isolat rizobakteri tergantung pada isolat yang diuji, 
kerapatan inokulum dan kemampuan isolat dalam mengkolonisasi akar tanaman (Thakuria et al., 2004).

\section{KESIMPULAN}

Interaksi antara jenis rizobakteri Necercia sp dengan kerapatan inokulum $10^{8} \mathrm{cfu} / \mathrm{ml}$ dan $P$. capacia dengan kerapatan inokulum $10^{9} \mathrm{cfu} / \mathrm{ml}$ secara efektif meningkatkan nilai indeks vigor dan berat kering kecambah normal.

\section{DAFTAR PUSTAKA}

Ali, B. 2015. Bacterial auxin signaling. Comparative study of growth induction in Arabidopsis thaliana and Triticum aestivum. Turkish Journal of Botany. 39 (1): 1-9.

Antoun, H, and D. Prevost. 2006. Ecology of plant growth promoting rhizobacteria. In: Siddiqui, Z. A. (ed.). PGPR: Biocontrol and Biofertilization. Springer, Dordrecht: 138.

Aswar, D. 2017. Pengaruh perlakuan benih dengan menggunakan agens biokontrol terhadap pengendalian penyakit Rhizoctonia solani dan pertumbuhan bibit cabai merah (Capsicum annuum L.). Skripsi. Program Studi Agroteknologi, Fakultas Pertanian Universitas Syiah Kuala, Banda Aceh.

Bae, Y. S., K. S. Park., Y. G. Lee and O. H. Choi. 2007. A simple and rapid method for functional analysis pf plant growth-promoting rhizobacteria using the development of cucumber adventious root system. Journal Plant Pathol. 23 (3) : 223-225.

Djamhuri, E. 2011. Pemanfaatan air kelapa untk meningkatkan pertumbuhan stek pucuk meranti tembaga (Shorea leprosula Miq). Fakultas Kehutanan IPB. Jurnal Silvikultur Tropika. 02 (1): 5-8.

Egamberdiyeva, D. 2007. The effect of PGPR on growth and nutrient uptake of maize in two different soils. Applied Soil Ecology. 36 (1) : 184-189.

Humaira, A. 2017. Efektivitas rizobakteri kandidat agens biokontrol terhadap daya hambat pertumbuhan koloni Phytium sp serta pengaruhnya terhadap viabilitas dan vigor dua varietas benih tomat (Lycopersicum esculentum Mill.). Skripsi. Program Studi Agroteknologi, Fakultas Pertanian Universitas Syiah Kuala, Banda Aceh.

Iqbal, A, and S. Hasnain. 2013. Auxin producing Pseudomonas strains : Biological candidates to modulate the growth of Triticum aestivum. Journal of Plants Sciences. $4: 1693-1700$.

Justice, O. L dan L. N. Bass. 2002. Prinsip dan Praktek Penyimpanan Benih (terjemahan Rennie Roesli ). PT. Raja Grafindo Persada, Jakarta.

Kloepper, J. W. 2003. A review of mechanisms for plant growth promotion by PGPR. Presented at the $6^{\text {th }}$ International PGPR Workshop, India.

Mardiah., Syamsuddin, dan Efendi. 2016. Perlakuan benih menggunakan rizobakteri pemacu pertumbuhan terhadap pertumbuhan vegetatif dan hasil tanaman cabai merah (Capsicum annuum L.). J. Floratek 11 (1) : 25-35.

Prakoso, R. Y. 2009. Respon perlakuan paska transportasi serta pemberian mikoriza dan rizobakteri pertumbuhan bibit jarak pagar (Jatropha curcas L.). Skripsi. Program Studi Pemuliaan Tanaman dan Teknologi Benih, Institut Pertanian Bogor, Bogor.

Reetha,S., G. Bhuvaneswari., P. Thamizhiniyan, and T. R. Mycin. 2014. Isolation of indole acetic acid (IAA) producing rhizobacteria of Pseudomonas flourescens and Bacillus

$\overline{\text { Perlakuan Rizobakteri Pemacu Pertumbuhan Tanaman (RPPT) dengan Beberapa Tingkat Kerapatan Inokulum }}$ Rizobakteri Terhadap Viabilitas dan Vigor Benih Cabai Merah Kadaluarsa (Capsicum annuum L.) (Dayang 
subtilis and enhance growth of union (Allium cepa L.). International Journal of Current Microbiology and Applied Science. 3 (2): 568-574.

Sutariati, G. A. K., Widodo, Sudarsono, dan S. Ilyas. 2006. Pengaruh perlakuan rizobakteri pemacu pertumbuhan tanaman terhadap viabilitas benih serta pertumbuhan bibit tanaman cabai. Bul. Agronomi. 34 (1) : 46-54.

Thakuria, D., N. C. Talukdar., C. Goswami., S. Hazarika., R. C. Boro, and M. R. Khan. 2004. Characterization and screening of bacteria from rhizospher of rice grown in acidic soil of assam. Curr Sci. 86: 978-985. 